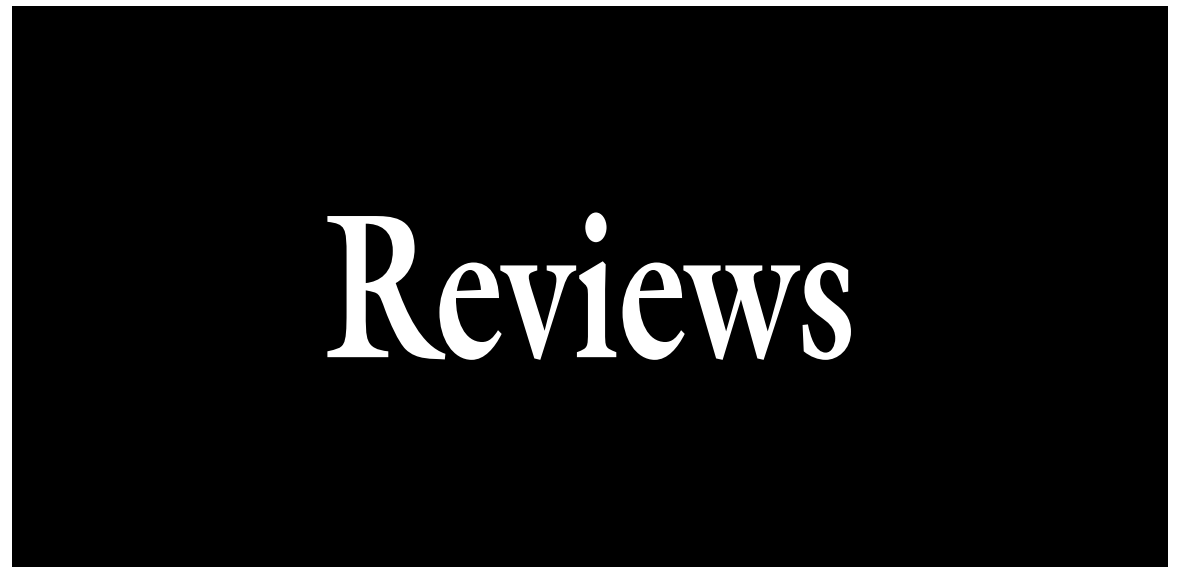

\section{Abiotic Factors Influencing Root Growth of Woody Nursery Plants in Containers}

\author{
H.M. Mathers ${ }^{1,6}$, S.B. Lowe ${ }^{2}$, C. Scagel ${ }^{3}$, D.K. Struve ${ }^{4}$, and \\ L.T. Case ${ }^{5}$
}

\begin{abstract}
ADDITIONAL INDEX WORDs. substrate, fiber pots, pot color, heat stress, root morphology, root periodicity, compost

SUMMARY. Container production has many advantages over traditional in-ground (field) production, including less damage occurring to the root system when transplanted, better establishment after transplanting, decreased labor and land acquisition costs for production, and increased product availability and longevity in the retail market. Growing plants in containers, however, alters root growth and function and can change root morphology. Numerous factors influence root growth in containers. Roots of container-grown plants are subjected to temperature and moisture extremes not normally found in field production. The effects of substrate aeration (Ea) as well as water holding capacity $(\mathrm{Pv})$ interact with different pot characteristics, resulting in changes to root morphology. Successful plant establishment after transplanting is often linked to root health. This review focuses on the roles of substrate physical and chemical properties, container characteristics, and temperature in altering root growth in container-grown woody nursery crops. Root circling, planting too deeply or "too-deep syndrome" (TDS), and the use of composts as container substrates will also be examined.
\end{abstract}

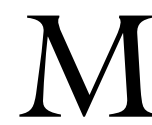
ore than $50 \%$ of the $\$ 26$ billion wholesale production of woody nursery crops in the United States is produced in containers (Hall et al., 2005). In
$2003,85 \%$ of broadleaf evergreen, $58 \%$ of coniferous evergreen, and $45 \%$ of deciduous shade tree commercial production was in containers (U.S. Department of Agriculture, 2004). Container production has several advantages over traditional inground (field) production (Gilman and Beeson, 1996; Harris and Gilman, 1991), and the packaged look of the finished potted plant appeals to consumers. Plants grown in containers are easier to handle and transport and are less prone to injury compared with balled and burlapped root balls. Growing plants in containers expands the window of marketability of the finished products, particularly in cool climates. Field-grown plants can only be harvested and marketed in a narrowtime frame, whereas container-grown plants can be shipped anytime in the growing season. Container production also requires no digging, thus reducing labor and equipment costs for removing plants from the ground (Whitcomb, 1984).

The greatest advantage of container production over field production may be seen in establishment success after transplanting, or in transplant quality (Gilman, 2001; Nillson and Örlander, 1995). Water stress after transplanting is probably the most limiting factor for plant growth and the major factor responsible for transplanting failure (Ferrini et al., 2000). This is especially true of container-grown plants. Gillman and Beeson (1996) state that, when regularly irrigated, trees from a variety of production systems performed equally well. Mathers et al. (2005) described in a 2-year study comparing container-grown tree liners of Autumn Blaze ${ }^{\mathrm{TM}}$ red maple (Acer $\times$ freemanii 'Jeffersred'), 'Prairifire' crabapple (Malus sp.), eastern redbud proprietary product, or vendor does not constitute guarantee or warranty of the product by the U.S. Dept. of Agriculture and does not imply its approval to the exclusion of other products or vendors that may also be suitable.

${ }^{1}$ Associate Professor, Department of Horticulture and Crop Science, Ohio State University, Columbus, Ohio

${ }^{2}$ Dawes Arboretum, Newark, Ohio. Former graduate student

${ }^{3}$ Research Plant Physiologist, USDA-ARS-Horticultural Crops Research Laboratory, Corvallis, Oregon

${ }^{4}$ Professor, Department of Horticulture and Crop Science, Ohio State University, Columbus, Ohio

${ }^{5}$ Research Associate, Department of Horticulture and Crop Science, Ohio State University, Columbus, Ohio

${ }^{6}$ Corresponding author. E-mail: mathers.7@osu.edu.

\begin{tabular}{llll}
\hline $\begin{array}{l}\text { Units } \\
\begin{array}{l}\text { To convert U.S. to SI, } \\
\text { multiply by }\end{array}\end{array}$ & U.S. unit & SI unit & $\begin{array}{l}\text { To convert SI to U.S., } \\
\text { multiply by }\end{array}$ \\
\hline 0.0283 & $\mathrm{ft}^{3}$ & $\mathrm{~m}^{3}$ & 35.3147 \\
3.7854 & gal & $\mathrm{L}$ & 0.2642 \\
2.54 & inch $(\mathrm{es})$ & $\mathrm{cm}$ & 0.3937 \\
25.4 & inch $(\mathrm{es})$ & $\mathrm{mm}$ & 0.0394 \\
0.4536 & $\mathrm{lb}$ & $\mathrm{kg}$ & 2.2046 \\
1.1209 & $\mathrm{lb} / \mathrm{acre}$ & $\mathrm{kg} \cdot \mathrm{ha}^{-1}$ & 0.8922 \\
16.0185 & $\mathrm{lb} / \mathrm{ft}^{3}$ & $\mathrm{~kg} \cdot \mathrm{m}^{-3}$ & 0.0624 \\
1 & $\mathrm{meq} / 100 \mathrm{~g}$ & $\mathrm{cmol} \cdot \mathrm{kg}^{-1}$ & 1 \\
1 & $\mathrm{mmho} / \mathrm{cm}$ & $\mathrm{dS} \cdot \mathrm{m}^{-1}$ & 1 \\
0.0010 & $\mathrm{Oz} / \mathrm{ft}^{3}$ & $\mathrm{~g} \cdot \mathrm{cm}^{-3}$ & 998.8379 \\
1 & $\mathrm{ppm}$ & $\mathrm{mg} \cdot \mathrm{L}^{-1}$ & 1 \\
$\left({ }^{\circ} \mathrm{F}-32\right) \div 1.8$ & ${ }^{\circ} \mathrm{F}$ & ${ }^{\circ} \mathrm{C}$ & $\left(1.8 \times{ }^{\circ} \mathrm{C}\right)+32$
\end{tabular}

Hortechnology • April-June 2007 17(2) 
(Cercis canadensis), and red oak (Quercus rubra) to similar height and caliper bareroot liners. They found container-grown materials had higher survival rates, caliper, and height growth and shortened production time compared with the bareroot stock.

The root system of containergrown plants is packaged, and transplant stress is minimized compared with field-grown stock. During digging and handling of bareroot and balled and burlapped (B\&B) stock, many fine roots, accounting for up to $30 \%$ of a plant's root area, are left in the soil, lost, or damaged (Thomas, 2000 ). These fine roots are generally feeder roots responsible for water and nutrient uptake. When these roots are damaged or lost, the plant is put under considerable stress and in some cases declines after transplanting (Harris and Gilman, 1991, 1993). In container production, however, plants are produced, handled, and transplanted with intact root systems, thus increasing the potential for transplanting success.

If the primary advantage of container vs. field production is based on an intact and functional root system in container-grown plants, then it is important to understand the factors that influence root growth in containers to achieve optimal benefits from container production. This review addresses several abiotic factors influencing root growth in containers: physical and chemical properties of substrates, pot characteristics, and temperature. We will briefly discuss current knowledge in these areas and summarize potential areas of new research important for optimizing root growth in container production of woody nursery crops.

\section{Growing substrates}

General selection criteria for an appropriate nursery substrate should include the following characteristics: salt free, high cation-exchange capacity (CEC), suitable physical and chemical properties, supportive, pest free, inexpensive, available, uniform, and light weight. Some common substrate components used in the nursery industry today are pine bark, hardwood bark, sand, soil, industrial clays and aggregates, composted yard, garbage and animal wastes such as biosolids/sludge, rice hulls, peanut hulls, mushroom compost, peatmoss, coir (a by-product of mat, brush, mattress, floor tile, and rope manufacturing from coconut mesocarp fibers), sawdust, bagasse (a by-product of the sugar industry), perlite, vermiculite, crumb rubber (derived from scrap tires), and cotton gin trash. The composition of substrates varies in different parts of the United States. Pine bark/sand (8:1) substrates are the industry standard in the southeastern United States for containergrown ornamental plants. In Ohio, a common mix is $60 \%$ bark (one-third green bark, one-third semicomposted, one-third composted), $20 \%$ rice hulls, $10 \%$ composted sewage sludge (Comtil; Kurtz Bros., Inc., Groveport, Ohio), and $10 \%$ sand or haydite (expanded and vitrified selected shale produced in rotary kilns at temperatures in excess of $2000^{\circ} \mathrm{F}$ ).

\section{Physical properties}

Physical properties of substrates known to affect roots include $\mathrm{Ea}, \mathrm{Pv}$, total porosity $(\mathrm{E})$, percentage of fine $(<0.5 \mathrm{~mm})$ particles, and bulk density $\left(D_{b}\right)$. These properties interact to influence the growth, function, and morphology of root systems growing in containers. Component selection for substrates is often more a function of cost and availability than of physical properties (Jones and Or, 1998; Raviv et al., 2004). Understanding how substrate physical properties influences root growth is important to developing the cultural practices (e.g., container type, irrigation strategy) that may be required to overcome inherent limitations of substrates selected for use in container production. Summaries of the physical properties of container substrates are given by Beardsell et al. (1979) and Handreck (1983). Simple laboratory methods can be used to determine substrate physical properties (Altland, 2006).

POROSITY AND WATER HOLDING CAPACITY. Ea is the amount of air space in a substrate after free water has drained out $[\mathrm{Ea}=($ aeration pore volume/container volume) $\times 100 \%]$ (Fonteno, 1987). Pv is the amount of water in a substrate after free water has drained out $[\mathrm{Pv}=$ (volume of water after free drainage/total volume of water at saturation) $\times 100 \%]$. $\mathrm{E}$ is the total space that can be filled with either water or air in the substrate.
The importance of adequate Ea in container production cannot be overemphasized. $\mathrm{Pv}$ is important but is secondary in its effects on root growth. Because roots require adequate oxygen to grow and function properly, a poorly aerated substrate will restrict root growth and plant development (Pokorny, 1987). Too little Ea results in plants that grow slowly and that are predisposed to other environmental stresses, such as winter injury, pests, and diseases. Container-grown roots are thought to respire more than roots grown in mineral soil because of faster plant growth rates and therefore require more oxygen for growth (Argo, 1998a). Too much $E_{\mathrm{a}}$ is not bad but results in an increase in irrigation frequency to maintain adequate moisture for plant growth.

There are no universally accepted standards for substrate physical properties (Bilderback et al., 2005). For container-grown woody plants, some suggest ranges of $20 \%$ to $30 \%,>50 \%$, and $20 \%$ to $25 \%$, respectively, for $\mathrm{Ea}$, $\mathrm{E}$, and $\mathrm{Pv}$ (Fonteno, 1987; Mathers and Leidenfrost, 1995). Yeager et al. (1997) suggest ranges of $10 \%$ to $30 \%$, $50 \%$ to $85 \%$, and $25 \%$ to $35 \%$, respectively, for Ea, E, and Pv. Some conflicting values have been reported, especially for Ea. Jarvis et al. (1996) reported that an Ea range of $10 \%$ to $20 \%$ is sufficient for most plants, while others indicate that Ea values of $15 \%$ result in poor drainage. Most sources agree that Ea values above $30 \%$ are considered too high (Bilderback, 1982; Handreck and Black, 1984). Ownley et al. (1990) found that severity of root rot incited by Phytophthora cinnamomi was negatively correlated with medium $\mathrm{E}$ and $\mathrm{Ea}$ and positively correlated with $\mathrm{D}_{\mathrm{b}}$ and Pv. They also indicated Ea must be $>20 \%$ to reduce host susceptibility to $P$. cinnamomi, by promoting root growth and maintaining root cell membrane integrity.

Several factors can influence Ea and $\mathrm{Pv}$ of substrates used in container production, including substratespecific factors such as particle size distribution, composition, $\mathrm{D}_{\mathrm{b}}$, and time (or aging). It is important to test the Ea and Pv of substrates used in production of container-grown woody plants, and it may be necessary to develop species-specific cultural criteria to optimize production. 
Methods of predicting hydrological properties of substrates used in container production are summarized in Milks et al. (1989) and Spomer (1974).

Particle size. Substrates used in container production generally contain a wide range of particle sizes. Definitions vary, however; in general, coarse components are $>0.8 \mathrm{~mm}$ (Argo, 1998b), while fine components are $<0.5 \mathrm{~mm}$ (Bilderback et al., 2005). Argo (1998b) describes two types of pores within a substrate: capillary and noncapillary. Capillary pores $<0.3 \mathrm{~mm}$ retain most of the water after an irrigation event, whereas noncapillary pores $>0.3 \mathrm{~mm}$ retain only a small amount of water. Although coarse components are good for increasing Ea of a substrate, coarse components have little value for water retention or nutrient exchange. Fine components increase the $\mathrm{Pv}$ and nutrient-exchange capacities of substrates. Argo (1998b) also states that particle sizes between 0.01 and $0.8 \mathrm{~mm}$ retain water; however, particle sizes from 0.8 to $6.0 \mathrm{~mm}$ increase the proportion of large noncapillary pores, thus increasing the amount of space occupied by air after irrigation. The shapes and diversity of particle sizes in substrates results in different particle arrangements within containers and can also alter pore sizes and distributions (Jones and Or, 1998).

Substrates with a high percentage of fine particles can result in low Ea and poor drainage. Low availability of oxygen can retard root growth and function and decrease overall plant growth. Guidelines for container substrate at a large commercial nursery in Oklahoma indicate that a desirable container medium should have $>6 \%$ of the particles as fines. Robbins (2002), however, reported that substrate physical properties thought to have negative effects on transplanting success (porosity $<10 \%$, fines $<65 \%$ ) did not appear to decrease the growth of three woody species. Beeson (1996) found that root system development of evergreen azalea (Rhododendron indicum) and variegated tobira (Pittosporum tobira $\times$ variegata) declined as compost percentages increased above $40 \%$ due to decreases in Ea within the substrate and suggested that, perhaps, an increase of fine particles $(<0.5 \mathrm{~mm})$ resulted in the low Ea.
The $E_{\mathrm{a}}$ of substrates can be increased by increasing the percentages of coarse particles or using deeper containers; however, too high a proportion of coarse components can decrease $P_{\mathrm{v}}$, efficiency of water and fertilizer use, efficiency of root function, and plant vigor. Knowing the size classes of substrate components is important for controlling the aeration, water, and nutrient availability when developing substrates for use in container production. Research on particle size distribution in substrates has primarily focused on its effects on $P_{\mathrm{v}}$ and $E_{\mathrm{a}}$. Little research has been done to assess the influence of particle sizes on the efficiency of water or fertilizer use in container production.

BULK DENSITY $\left(D_{b}\right) . \quad D_{b}$ is defined as the weight per volume a substrate occupies including solid particles and pore spaces. Substrate compaction can alter $\mathrm{Ea}$, root system morphology, and whole plant growth. Yeager et al. (1997) suggest a $D_{b}$ range of 0.19 to $0.7 \mathrm{~g} \cdot \mathrm{cm}^{-3}$ dry weight for substrates used in container production. Compaction results in an increase in $\mathrm{D}_{\mathrm{b}}$ and occurs in container production as a result of physical handling of the substrate, pot configuration, particle size distribution, and time. Bilderback et al. (2005) found that, at planting, $D_{b}$ values of aged and fresh pine bark/sand (8:1) substrate were 0.19 and $0.17 \mathrm{~g} \cdot \mathrm{cm}^{-3}$, respectively; however, after $56 \mathrm{~d}$ the $\mathrm{D}_{\mathrm{b}}$ had increased to $0.32 \mathrm{~g} \cdot \mathrm{cm}^{-3}$ for both substrates. Changes in $\mathrm{D}_{\mathrm{b}}$ during production can negatively affect other substrate physical properties and consequently root growth and function.

In most cases, increased substrate $\mathrm{D}_{\mathrm{b}}$ above a certain threshold decreases root growth and ultimately decreases growth of the whole plant. Ferree et al. (2004) found root dry weight of container-grown apple (Malus $\times$ domestica) in Orville silt loam soil $(20 \%$ sand, $62 \%$ silt, $18 \%$ clay) with $\mathrm{a} \mathrm{D}_{\mathrm{b}}$ of $1.2 \mathrm{~g} \cdot \mathrm{cm}^{-3}$ was greater than when grown at $1.4 \mathrm{~g} \cdot \mathrm{cm}^{-3}$ $\mathrm{D}_{\mathrm{b}}$. Increasing $\mathrm{D}_{\mathrm{b}}$ to $1.5 \mathrm{~g} \cdot \mathrm{cm}^{-3}$ reduced shoot length, leaf area, leaf size, and dry weight of shoots, leaves, and roots. Maupin and Struve (1997) found that growth of red oak (Quercus rubra) in Wooster silt loam (25\% sand, $60 \%$ silt, $15 \%$ clay) was not influenced at a $1.5 \mathrm{~g} \cdot \mathrm{cm}^{-3} \mathrm{D}_{\mathrm{b}}$ but was reduced by a $D_{b}$ of $1.75 \mathrm{~g} \cdot \mathrm{cm}^{-3}$. When containergrown lodgepole pine (Pinus contorta) trees were grown in a loam soil (46\% sand, $47 \%$ silt, $7 \%$ clay) above $1.7 \mathrm{~g} \cdot \mathrm{cm}^{-3}$, trees had shorter needles and lower root dry weight (Conlin and van den Driessche, 1996).

Although Ferree et al. (2004) found substrate compaction in containers had major effects on plant growth, there was little effect of compaction on photosynthesis, suggesting that carbon supply was not the major factor limiting growth in compacted substrate. Wilson et al. (2003) compared growth of perennial sage species (Salvia spp. 'Van Houttei', $S$. gauranitica 'Black and Blue', $S$. longispicata $\times S$. farinaceae) grown in compost and peat-amended substrate. They found that, even though compost-amended substrates had higher $D_{b}$, higher particle density and yielded lower plant growth than peat-amended substrates, the plants grown in the compost-amended substrates were still considered marketable.

For some species, substrate compaction can enhance growth but may decrease container stock quality. Zahreddine et al. (2004) reported root and shoot weight of Austrian pine (Pinus nigra) grown in a compacted $\left(0.71-1.01 \mathrm{~g} \cdot \mathrm{cm}^{-3}\right)$ substrate ( 1 vermiculite $: 1$ peatmoss : 1 perlite) was greater than when grown in uncompacted $\left(0.39 \mathrm{~g} \cdot \mathrm{cm}^{-3}\right)$ substrates; however, root malformation was also greatest when grown in compacted substrate. Compaction of 1.01 and $1.10 \mathrm{~g} \cdot \mathrm{cm}^{-3}$ resulted in root circling, which may decrease plant performance after transplanting.

The influence of compaction on root growth and establishment success has not been investigated for a wide range of woody nursery plants. Because many urban soils are considered compacted, and many plant stresses can be partially alleviated by previous exposure or preconditioning, there may be an advantage to growing certain species in substrate with high $\mathrm{D}_{\mathrm{b}}$ to precondition plants to a root environment with low oxygen, denser substrate, and low water availabilities. We speculate that high $\mathrm{D}_{\mathrm{b}}$ in container production are more widespread than realized and are potentially detrimental to plant survival after transplanting into the landscape. Again, the results reported by Zahreddine et al. (2004) indicated 
that, even though plants in higher $\mathrm{D}_{\mathrm{b}}$ substrate produced more root and shoot mass, they also had an increased incidence of root malformations. It is possible that some of the root malformation issues experienced after transplanting into the landscape may have been initiated in production by less than optimum substrate $D_{b}$. This should be explored in future investigations.

Placing plants too deep, so that the soil covering the roots smothers them, is a major concern and focus of research in the nursery/landscape industry. Planting too deep can stop the plant from growing and eventually it leads to the death of the plant. All species can suffer from "too-deep syndrome" (TDS); however, ericaceous plants (Cameron et al., 1999) and other shallow-rooted species are especially vulnerable. The interacting affects of substrate $D_{b}$, depth of planting and transplanting survival should be the subject of future research.

Decomposition. Characteristics of substrate components can change over time (Allaire-Leung et al., 1999) and result in changes to substrate physical characteristics that influence root growth. Substrate components should not only be chosen for their physical properties but also for the stability of these properties over time. Bark, a common substrate component used in container production of woody species in the United States and Canada, provides good aeration, especially when mixed with peat. Coarse sawdust that is well decomposed is also useful as a substrate component. Fresh sawdust has high aeration porosity; however, rapid decomposition can result in a dramatic decrease in Ea over time. Bark has high lignin content and is more resistant to decomposition. Hardwood bark is $45 \%$ cellulose and $55 \%$ lignin and decomposes more readily than softwood bark, which is $10 \%$ cellulose and 90\% lignin (T. Bilderback, personal communication). Ea should not vary as greatly when bark is used as a nursery substrate compared with sawdust. Perlite and vermiculite are not subject to decomposition, but Ea can be lost due to compaction, especially with high vermiculite percentages.

The ratio of carbon to nitrogen (C:N ratio) varies with substrate components (e.g., sawdust, 1000:1; rice hulls, 500:1; conifer bark, 300:1; hardwood bark, 150:1; coir, 80:1; peat, 58:1). Generally, components with high $\mathrm{C}: \mathrm{N}$ ratios tie up nutrients from fertilizers and decrease fertilizer efficiency during production. Rice hulls, however, are an exception due to their high silica content that increases substrate CEC. To enhance decomposition in bark substrates, it was formerly recommended that growers add $\approx 1 \mathrm{~kg}$ of $\mathrm{N}$ per cubic meter of bark. This procedure is contrary to current best management practices, and many growers now compost high $\mathrm{C}: \mathrm{N}$ organic components until they decompose to lower $\mathrm{C}: \mathrm{N}$ ratios.

\section{Compost}

Compost materials are being used extensively in the nursery industry and in some cases to replace peatmoss. Effects of compost materials on root growth in containers are a function of their interactive effects not only on substrate physical properties but also on substrate chemical and biological properties.

The physical (Pv, Ea) and chemical $(\mathrm{pH})$ properties of composted materials can change over time (Kraus et al., 2000). Changes in Ea over time may be higher with the compostamended substrate than with peatmoss-amended substrate (Raviv and Medina, 1997). Bunt (1961) discussed other effects of compost on plant growth and found that compaction of compost materials over time can influence root growth and function. Composted materials often lack the coarse, large particles necessary for adequate aeration, and as they decompose their effects on Ea become more pronounced, leading to possible waterlogging and anoxia of roots (Bilderback and Jones, 2001 ); therefore, composted materials are never used in amounts $>50 \%$ by volume for most container substrates (Bilderback et al., 2005). Animal waste composts usually have high EC and nutrient levels and are generally limited to $10 \%$ to $30 \%$ by volume of potting substrates. Composts usually have a "liming effect" (raising the $\mathrm{pH}$ ), so no dolomitic lime should be added, and minor element supplements are often not required (Bilderback et al., 2005).

Serra-Wittling et al. (1996) found that at different matric potentials, water potential was 2.54.5 times greater in compost than in the soil. The higher $\mathrm{Pv}$ of compost is due to a smaller pore size compared with the pore size of mineral soil. Cole et al. (2005) determined that physical properties (particularly $\mathrm{Pv}$ ) of a $100 \%$ pine bark $(\mathrm{PB})$ substrate were significantly improved with amendment by cotton gin compost (CGC). They concluded that irrigation could be reduced using 3:1 PB/CGC substrate without reduction of plant growth or quality compared with $100 \%$ PB. Future research should investigate the use of compost $\mathrm{Pv}$ values to increase irrigation efficiencies.

The effects of composts on $\mathrm{Pv}$ may indirectly influence other substrate attributes in container production, such as temperature. Comtil, a compost of municipal solids mixed with pine bark, is commonly used in Ohio container production for its reported growth enhancement, disease suppression, and general stress reduction properties (H. Hoitink, personal communication). In a study comparing substrates with $0 \%, 10 \%$, and $20 \%$ Comtil in 1 -gal containers, increasing the amount of Comtil in the substrate decreased substrate temperature by $1.1-1.3{ }^{\circ} \mathrm{C}$ and increased shoot and root weights (S.B. Lowe, H.M. Mathers, and S.K. Struve, unpublished).

Addition of compost to substrate has long been observed to improve plant growth as well as decrease losses due to Phytophthora root rots in the nursery industry (Hoitink and DeCeuster, 1999; Hoitink et al., 1991; Kuter, 1988). Hoitink et al. (1997) found that incorporating compost into substrate can be as effective at controlling root rots as use of fungicides. Substrate amended with composted material has been found to suppress disease in both field and container production (Hoitink and DeCeuster, 1999).

\section{Chemical properties}

Chemical properties of container substrates, such as $\mathrm{pH}, \mathrm{CEC}$, soluble salts, pesticides, and copper coatings, can have a profound influence on root growth and function in containers. Understanding how substrate chemical properties influence roots is important for selecting substrate as well as development of cultural practices (e.g., substrate amendments, 
chemical and fertilizer additions) that result in providing the optimum nutrients for growth and minimizing the damage from potentially toxic compounds. A summary of some of the chemical properties of container substrates is given by Argo (1998a).

$\mathrm{pH} . \mathrm{pH}$ is a measure of hydrogen $\left(\mathrm{H}^{+}\right)$ions in solution. It is recorded on a logarithmic scale of 0 to 14 , with 7 being neutral. Substrate values above 7 are considered basic or alkaline, and those below 7, acid. The ability of roots to acquire and use nutrients is strongly influenced by $\mathrm{pH}$. The $\mathrm{pH}$ of substrate affects availability and solubility of some nutrients. The optimum $\mathrm{pH}$ of container substrate varies with plant species and some species grow best within a narrow range of $\mathrm{pH}$ values. Plants grown outside their optimum $\mathrm{pH}$ range can exhibit symptoms of nutrient toxicity or deficiency as well as stunted growth and poor performance.

In general, substrate $\mathrm{pH}$ should range from 5.4 to 6.0 and 6.2 to 6.8 in substrate that contain $>20 \%$ mineral soils. In high-pH substrates, ions of aluminum (Al), iron $(\mathrm{Fe})$, and manganese $(\mathrm{Mn})$ precipitate, and the availability of these elements decreases. Plants in a high-pH substrate may express deficiencies of $\mathrm{Fe}$, boron $(\mathrm{B})$, zinc $(\mathrm{Zn}), \mathrm{Mn}$, copper $(\mathrm{Cu})$, and molybdenum (Mo) (Mathers, 2003a). Phosphorus (P) may also become deficient in alkaline substrates because it complexes with calcium $(\mathrm{Ca})$ to form insoluble $\mathrm{Ca}$ phosphates. Plants in low-pH substrates may express toxicities in $\mathrm{Fe}$, $\mathrm{Mn}, \mathrm{Zn}$, and $\mathrm{Cu}$, deficiencies in $\mathrm{Ca}$ or magnesium $\mathrm{Mg}$, sensitivity to ammonium $\left(\mathrm{NH}_{4}^{+}\right)$, and leaching of phosphates $\left(\mathrm{PO}_{4}{ }^{-2}\right)$. Deficiencies of most of the micronutrients can be corrected by adjusting the substrate $\mathrm{pH}$.

One disadvantage of many peatand bark-based substrates is that these components have poor buffering capability, resulting in $\mathrm{pH}$ changes over time, even if the substrate is within the optimum $\mathrm{pH}$ range at planting. The $\mathrm{pH}$ in a substrate can shift depending on the alkalinity of irrigation water, liming effects, acidification of substrate by roots, and acid/base reactions of fertilizer (Bishko et al., 2002, 2003). Regular monitoring of substrate $\mathrm{pH}$ can be used to assess changes in $\mathrm{pH}$ and allow growers to correct $\mathrm{pH}$ problems before they become too serious. Information on $\mathrm{pH}$ management in container crops is addressed in Argo and Fisher (2002).

ExCHANGe CAPACITY, SOLUble SALTS, AND FERTILIZER. CEC refers to the interchange between cations in substrate solution and cations on negatively charged soil or organic colloids. It represents a substrate's nutrient holding capacity or the total exchangeable cations a substrate can retain per unit weight. The recommended CEC range for container substrate is 6 to $15 \mathrm{meq} / 100 \mathrm{~g}$. Cation binding strengths to particles, in order of strongest to weakest, are $\mathrm{H}^{+}>\mathrm{Ca}^{+2}>\mathrm{Mg}^{+2}>\mathrm{K}^{+}=\mathrm{NH}^{4+}>\mathrm{Na}^{+}$. Low substrate CEC in container production can increase the frequency of fertilizer applications compared with plants grown in soils.

Anions are nitrates $\left(\mathrm{NO}_{3}{ }^{-}\right)$, phosphates $\left(\mathrm{PO}_{4}{ }^{-2}\right)$, and sulfates $\left(\mathrm{SO}_{4}^{-2}\right)$. Most $\mathrm{NO}_{3}$, like other anions, is easily leached from container substrate by heavy rains or excessive irrigation. Periodic monitoring of substrate $\mathrm{NO}_{3}$ levels is essential in container production because $\mathrm{NO}_{3}$ availability is so important to plant growth and it so easily leached (Mathers, 2004).

Soluble salts (SS) come from fertilizers, organic matter used in the substrate, and salts in irrigation water. Plant sensitivity to SS can be cultivarspecific and vary with plant age and length of exposure. Periodic monitoring of SS will provide an estimate of the total dissolved salts in a container production system. One way to measure SS dissolved in water is by electrical conductivity (EC). Decisiemens per meter $\left(\mathrm{d} S \cdot \mathrm{m}^{-1}\right)$ is a commonly used unit for measuring EC. The relationship between the $\mathrm{EC}$ of water $\left(\mathrm{EC}_{\mathrm{w}}\right)$ and total dissolved salts is $\mathrm{EC}_{\mathrm{w}}$ $\times 640=$ total dissolved salts (in ppm or $\left.\mathrm{mg} \cdot \mathrm{L}^{-1}\right)$. The initial total dissolved salts of a substrate should be low, especially for salt-sensitive plants, liners, seedlings, and other young plant material.

Producers of container-grown nursery plants have been slow to adopt regular EC monitoring programs (Ruter and Garber, 1993). The Virginia Tech extraction method (VTEM), or pour-through method, is a simple, quick method that requires no special equipment, allows for testing in the field, requires no substrate handling, and reduces false high readings due to rupture of controlled-released fertilizers (CRFs) prills (Ruter and Garber, 1993). Table 1 presents values for interpretation of SS and $\mathrm{pH}$ measurements obtained by VTEM compared with an extraction method. Generally, EC values for plants fertilized with CRFs and evaluated with VTEM should range from 0.20 to $1.00 \mathrm{dS} \cdot \mathrm{m}^{-1}$.

Fertilizer selection and method of application profoundly influence the chemical properties of substrates used in container production. Fertilizer selection considers crop, cost, labor, substrate, growth stage, production time, and irrigation practices. For container production, methods of fertilizer placement include dibbling, top dressing, incorporation, and fertigation. Slow-release fertilizers (SRFs) and CRFs are the predominant types of fertilizer used in container production due their simplicity of use and potential for decreasing nutrient runoff. Although the terms SRF and CFR are often used interchangeably, the products they describe are different (Table 2). SRF can be divided into two groups: naturally occurring organic materials and low-solubility synthetic organic compounds. CRFs are coated with materials (e.g., polyethylene, acrylic resins, latex, waxes, and sulfur) that keep the fertilizer from being immediately soluble and available to plants. The labels and instructions on bags of SRFs and CRFs generally indicate their length of nutrient release; however, the manufacturer typically includes nutrient-release data that are based on laboratory conditions, not actual plant production. Thus, it is crucial to understand the production conditions that affect the nutrientrelease characteristics of different fertilizer formulations to predict their effects of substrate chemical properties.

Herbicides. Herbicide use in containers can directly affect root growth. Herbicides are applied shortly after potting and can reach the roots easily due to the large macropores that are present at this time. Certain precautions should be taken when using herbicides in container production, such as avoiding excessive leaching of herbicides into the root zone and selecting herbicides with lower leaching potentials (Altland, 2002). 
Table 1. Normal ranges and comparisons of soluble salt and $\mathrm{pH}$ measurements obtained in nursery container soilless substrates with various extraction methods. ${ }^{\mathrm{z}}$

\begin{tabular}{lclc}
\hline Method & $\mathrm{pH}$ & \multicolumn{1}{c}{ Soluble salt } & $\mathrm{EC}^{\mathrm{y}}\left(\mathrm{dS} \cdot \mathbf{m}^{-\mathbf{1}}\right)^{\mathrm{x}}$ \\
\hline VTEM $^{\mathrm{w}}$ & $5.2-6.2$ & Sensitive crops (liquid feed) & $0.50-0.75$ \\
& & Nursery crops (liquid feed) & $0.75-1.50$ \\
& & Nursery crops & $0.20-1.00$ \\
& & $\quad$ (controlled-release) & \\
SEM (nursery crops) & \multirow{2}{*}{$5.8-6.8$} & Low & $0.00-0.74$ \\
& & Acceptable & $0.75-1.49$ \\
& & Optimum & $1.50-2.24$ \\
& & High & $2.25-3.49$ \\
SEM (greenhouse crops) & $5.6-5.8$ & Very high & $3.50+$ \\
& & Low & $0.00-0.75$ \\
& & Acceptable & $0.75-2.0$ \\
& & Optimum & $2.0-3.5$ \\
& & High & $3.5-5.0$ \\
& & Very high & $5.0+$ \\
\hline
\end{tabular}

${ }^{\mathrm{z}}$ Ruter and Garber, 1993

${ }^{\mathrm{y}} \mathrm{EC}=$ electrical conductivity

${ }^{x} 1 \mathrm{dS} \cdot \mathrm{m}^{-1}=1 \mathrm{mmho} / \mathrm{cm}$.

"VTEM = Virginia Tech extraction method.

${ }^{v} \mathrm{SEM}=$ saturation extraction method.

The most common pre-emergent herbicides used in container production are oryzalin, prodiamine, pendimethalin, trifluralin, oryzalin + oxyfluorfen, isoxaben + trifluralin, pendimethalin + oxyfluorfen, and oxadiazon + prodiamine (Mathers, 2002). All of these registered herbicides are dinitroaniline (DNA) herbicides or contain DNA herbicides. Root inhibition and lodging frequently occur with DNA herbicides (Ashton and Crafts 1981; Hayes et al., 1999). Derr and Salihu (1996) found that a single application of oryzalin at a rate of $4.48 \mathrm{~kg} \cdot \mathrm{ha}^{-1}$ a.i. reduced overall root weight of abelia (Abelia xgrandiflora) by $25 \%$ and effectively stopped all new root growth. Despite the knowledge that DNAs are root inhibitors and that three to five applications of pre-emergent herbicides are not uncommon to keep the "chemical barrier" on the container substrate surface, few studies have investigated the effects of these herbicides on root development of the crop in container production.

Copper. Spinout (SePro, Carmel, Ind.) or copper hydroxide $\left[\mathrm{Cu}(\mathrm{OH})_{2}\right]$-treated containers are used in container production to eliminate root circling problems incited by the smooth sidewalls of plastic containers (Arnold and Struve, 1989b). The $\mathrm{Cu}$ acts as a growth regulator, stunting or killing the root tips and thus redirecting root growth. When the root tip contacts $\mathrm{Cu}(\mathrm{OH})_{2}$ on the sidewalls of the container, lateral root growth is redirected, resulting in increased secondary root branching and more fibrous root growth. $\mathrm{Cu}$ is strongly bound to soils and organic matter and is very immobile. $\mathrm{Cu}(\mathrm{OH})_{2}$-treated containers are usually effective for regulating root growth for one growing season in the container, and normal root growth generally resumes after the container is removed and the plant is transplanted into the landscape (Arnold and Struve, 1989a, 1993; Struve et al., 1994). Some researchers (Brass et al., 1996; Beeson and Newton, 1992) have reported that certain species [e.g., magnolias (Magnolia spp.), blue princess holly (Ilex $\times$ meserveae 'Blue Princess'), flowering dogwood (Cornus spp.), sweet gum (Liqidambar styraciflua), and weeping willow (Salix babylonica)] grown in $\mathrm{Cu}(\mathrm{OH})_{2}$-treated containers were slower to establish and grow in the landscape. Cultivar sensitivity to $\mathrm{Cu}(\mathrm{OH})_{2}$-treated containers has not been assessed completely.

\section{Root circling}

Root circling has been determined to cause long term damage to tree roots and trunks well after trees have been planted into the landscape (Harris et al., 2004). Air-root-pruning (ARP), accomplished by using containers with holes in the container wall or containers made of synthetic fabrics, has been demonstrated to minimize root circling by modifying or killing root tips (March and Appleton, 2004). Root circling is caused when nursery stock is not sold as early as anticipated and excessive time is spent in the container. It may be exacerbated by the smooth sidewalls of plastic containers and substrate compaction (Zahreddine et al., 2004). "Pot-bound" plants with a solid mass of circling roots will establish slowly and may continue root circling for many years after planting. Maynard et al. (2000) suggest that the incidence of root circling is a function of time in the pot and method of root control.

Root circling can lead to poor anchorage or even girdling (strangling) of the trunk. Vigilant observation of the growth of container-grown plant roots and appropriate action to prevent circling and stunting can offset permanent damage. Other possible causes of root circling can be container designs that do not induce roots to grow downward into the center of the container, an area usually less colonized by roots (Ferrini et al., 2000). Downward root growth results in a better root system, with fewer circling and kinking roots and with intact root tips (Fiorino et al., 1998).

To reduce circling root development, containers with internal ridges were designed. Vertical slits in the sides of containers (Stromberger, 2002) and chemical treatments to interior container surfaces including $\mathrm{Cu}(\mathrm{OH})_{2}$ (Arnold and Struve, 1989a) were later developed to reduce root malformation. Another strategy used included small holes in between woven strands in a fabric bag container as a method for mechanically pruning roots (Appleton, 1993). Many early root pruning strategies incorporated air pruning of tap roots during seedling propagation (Arnold and McDonald, 1999).

TDS is also thought to result in root circling (Johnson and Hauer, 2000). There are three possible explanations for why landscape plants are planted too deep: nursery culture (e.g., planting, cultivation, digging too small a ball); tree planting (e.g., deep holes, root balls sinking into backfill, buried by landscape fill, excessive mulch); and changes to established tree environment (e.g., fill over roots, excessive mulch, water table changes, compaction). 
Table 2. Groups, examples, descriptions, and factors affecting nutrient release of controlled-released (CRF) and slow-released (SRF) fertilizers, the predominant types of fertilizer used in soilless nursery container substrates. ${ }^{\mathrm{z}}$

\begin{tabular}{|c|c|c|c|}
\hline Fertilizer type $^{y}$ & Examples & Main factors & Comments \\
\hline \multicolumn{4}{|l|}{ Organic SRF } \\
\hline Animal by-products & $\begin{array}{l}\text { Hoof and horn mixtures, } \\
\text { dried blood, urea, manures }\end{array}$ & $\begin{array}{l}\text { Microbial activity } \\
\text { (fungal and } \\
\text { bacterial) }\end{array}$ & $\begin{array}{l}\text { Small particle size, moderately } \\
\text { high temperatures and water } \\
\text { content speeds breakdown } \\
\text { and could give rise to } \\
\text { conditions of ammonia } \\
\text { toxicity. }\end{array}$ \\
\hline \multicolumn{4}{|l|}{ Low-solubility SRF } \\
\hline $\begin{array}{l}\text { Magnesium ammonium } \\
\text { phosphate }\end{array}$ & MagAmp $^{w} 7 \mathrm{~N}-17.46 \mathrm{P}-4.98 \mathrm{~K}$ & $\begin{array}{l}\text { Chemical hydrolysis, } \\
\text { particle size, and } \\
\text { moisture }\end{array}$ & $\begin{array}{l}\text { Low } \mathrm{pH} \text { and high moisture } \\
\text { content increase the rate of } \\
\text { release. Low nitrogen and } \\
\text { high phosphorous. }\end{array}$ \\
\hline \multicolumn{4}{|c|}{ CRF (also known as coated fertilizers) } \\
\hline Sulfur-coated urea (SCU) & $\begin{array}{l}\text { Scotts' Poly-S }{ }^{\mathrm{u}} \text {, John Deere } \\
\text { Landscapes' SCU }\end{array}$ & $\begin{array}{l}\text { Coating thickness, } \\
\text { substrate } \\
\text { temperature, } \\
\text { and moisture }\end{array}$ & $\begin{array}{l}\text { Imperfections in coating may } \\
\text { cause a high and sudden } \\
\text { release. More even release } \\
\text { achieved in next generation } \\
\text { SCUs such as Scott's Poly-S } \\
\text { and John Deere Landscapes' } \\
\text { SCU. Microorganisms also } \\
\text { break down the coating. }\end{array}$ \\
\hline $\begin{array}{l}\text { Resin- and polyurethane- } \\
\text { and polyolefin-coated } \\
\text { materials }\end{array}$ & $\begin{array}{l}\text { Osmocote Plus }{ }^{\mathrm{u}} 15 \mathrm{~N}-3.93 \mathrm{P}-9.96 \mathrm{~K} \\
\text { Apex }^{\mathrm{s}} 21 \mathrm{~N}-2.2 \mathrm{P}-5.28 \mathrm{~K} \\
\text { Nutricote } \\
\text { and Multicote } 18 \mathrm{~N}-2.62 \mathrm{P}-6.64 \mathrm{~K} \\
\text { an }-3.08 \mathrm{P}-12.45 \mathrm{~K}\end{array}$ & $\begin{array}{l}\text { Coating thickness } \\
\text { and substrate } \\
\text { temperature }\end{array}$ & $\begin{array}{l}\text { Research indicates that release } \\
\text { rates from fertilizer held at } \\
100^{\circ} \mathrm{F}\left(37.7^{\circ} \mathrm{C}\right) \text { could be } \\
\text { up to } 60 \% \text { higher than those } \\
\text { from fertilizer held at } 80^{\circ} \mathrm{F} \\
\left(26.7^{\circ} \mathrm{C}\right) \text {. }\end{array}$ \\
\hline
\end{tabular}

${ }^{2}$ Cabrera, 1997.

ySome fertilizers may be made up of a combination of different controlled-release formulations. For example, Woodace $18 \mathrm{~N}-2.18 \mathrm{P}-8.3 \mathrm{~K}$ contains both IBDU and polymercoated urea. Always read labels and instructions on fertilizer bags or associated technical literature before use.

${ }^{\mathrm{N}} \mathrm{Nu}$-Gro Technologies, Inc., St. Louis.

wSumitono Corporation of America, New York

'Lebanon Seaboard Corp., Lebanon, PA.

"The Scotts Co., Marysville, OH.

tDeere and Co., Moline, IL.

s.R. Simplot Co., Boise, ID

${ }^{\mathrm{r}}$ Chisso-Asahi Fertilizer Co., Ltd., Tokyo.

${ }^{q}$ Haifa Chemicals, Ltd., Haifa Bay, Israel.

The depth from the soil surface to the root system affects root circling because roots respond to oxygen limitations by growing into oxygen-sufficient areas, typically near the soil surface. The ascent of roots to the surface often causes roots to lose their normal outward radiating pattern (Johnson and Hauer, 2000). Roots that radiate toward the stem can later become stem-girdling roots (SGRs). SGRs enlarge over time and, in combination with the normal enlargement of the buried stem, create a compressed, weak point in the tree's stem
(Harris et al., 2004). There is a general decline in the remaining root system, and movement of water and nutrients is impeded due to stem compression (Johnson and Hauer, 2000). Trees with SGRs may suffer slow decline, severe dieback, and cambial death following cold winters or periodic drought, die prematurely, or fail suddenly in wind and ice storms.

\section{Container characteristics}

Because root growth is restricted to the volume of substrate a container can hold, it is not surprising that pot characteristics have a significant impact on root and plant growth. The delicate balance between roots and shoots can be upset when the root system is restricted in a small rooting volume (NeSmith and Duval, 1998). The resulting imbalance can have short- and long-term effects on plant growth. Plants grown in containers in general have different root morphology than field-grown plants (NeSmith and Duval, 1998). Root restrictions can result in a loss of primary roots and an increase in the number of lateral roots $(\mathrm{NeSmith}$ and 
Duval, 1998), and container type can alter root orientation (Marshall and Gilman, 1998).

Container geometry. Bilderback and Fonteno (1991) observed that container geometry and substrate selection have a pronounced effect on $\mathrm{Pv}$ and $\mathrm{Ea}$. As container height and width decrease, $\mathrm{Pv}$ increases and Ea decreases. Substrate properties such as E, unavailable water content, and $\mathrm{D}_{\mathrm{b}}$ are unaffected by pot size. A perched water table is created in the bottom of all containers that further restricts the total root growing space (Mathers and Leidenfrost, 1995). This perched water table is an area where all the pore spaces in the substrate are filled with water and occurs no matter how many drainage holes are in the container. As the depth of the container increases, the impact of the saturated area at the bottom of the container lessens because it becomes a smaller percentage of total pot size.

Substrates in short containers have lower Ea than in taller containers. Deeper containers exhibit greater overall Ea and fewer pores filled with water and thus are best for optimum aeration and drainage. One criticism of deep containers is that roots do not grow laterally in the container and grow slowly after transplanting, resulting in plants that are more subject to blow over. However, the lack of lateral root development, out of deep containers, may be more an issue of root circling. Circling roots in the container before transplanting is frequently the cause of poor lateral root development after transplanting. The influence of pot geometry on root development and morphology has been discussed by others (Appleton, 1993, 1995). Plants with circling roots do not regain normal growth after plants are removed and planted in the landscape.

Container size. The effects of container size on roots are related to container geometry and to volume of substrate. Container volume has been reported to limit basic plant growth requirements of space, water, air, and nutrients (Swanson, 1995). Container-grown plants can have abnormal buttress root development beginning when seedlings are grown in deep cells with narrow diameters (Zahreddine et al., 2004). Root malformations and circling can also occur from container design and restrictions. Altered root morphology may be more pronounced with smaller containers and can predispose plants to drought stress (NeSmith and Duval, 1998).

Meyer and Cunliffe (2004) determined that container size had a significant effect on root and shoot growth of ornamental grasses. Height and crown diameter increased as the container size increased and was thought to be strictly a function of increased container volume. Keever et al. (1985) reported that shoot growth of Burford holly (Ilex cornuta), Japanese euonymus (Euonymus japonica), and azalea (Rhododendron spp.) were positively correlated with pot size. Spreading euonymus (Euonymus kiautschovia) grown in large containers grew more rapidly than those grown in smaller containers, and root restriction was found to increase root/shoot ratios by decreasing biomass partitioning to the main stem (Dubik et al., 1990).

Using larger containers, however, does not necessarily improve establishment after transplanting into the landscape. Plants grown in smaller containers sometimes establish more rapidly than plants grown in larger containers. Mountain laurel (Kalmia latifolia) established better in hot, dry environments after transplanting from 7.6-L containers than when transplanted from 19-L containers (Hanson et al., 2004). This suggests that smaller plants are less vulnerable to environmental stress during the first season after transplanting and will possibly establish more successfully in the landscape. Lauderdale et al. (1995) found that smaller plants have higher leaf conductance, water use efficiency, and shoot elongation after transplanting than larger plants, indicating less transplant stress. They concluded that smaller plants are better candidates for transplanting in most circumstances because they recover from transplant shock more quickly than larger plants. However, Weston and Zandstra (1986) stated that transplants with relatively large root systems generally suffer less posttransplanting stress and thus come into production earlier than plants with small root systems.

Newby and Fare (2001) found smaller liners of Red Sunset red maple (Acer rubrum 'Franksred') potted into larger containers produced significantly better height and caliper growth. Plants grown from 0.5 -inch caliper liners had greater height and caliper growth than plants grown from 0.75 -inch and 1.0 -inch liners after 18 months of production. When plants were transplanted into 15 -gal pots, they had greater height growth than those grown in 7 -gal or 10 -gal containers. Container-grown plants may also have abnormal buttress root development beginning when seedlings are grown in deep cells with narrow diameters (Zahreddine et al., 2004). Root malformations and circling can also occur from container design and restrictions. These alterations in root morphology may be more pronounced with smaller container sizes and could predispose plants to drought stress in out-planting because a significant reservoir of soil water resources goes unexplored (NeSmith and Duval, 1998).

Container size can also influence temperature within the substrate. Mortality from high temperatures may be higher in smaller containers (Wright et al., 2001) due to decreased distance between container walls (highest temperatures) and the container center (lowest temperatures) (Martin and Ingram, 1993). Martin et al. (1991) found the maximum temperature at the container center was 4.8 and $6.3{ }^{\circ} \mathrm{C}$ lower for $57-\mathrm{L}$ than for $27-\mathrm{L}$ and $10-\mathrm{L}$ containers, respectively. As container volume increased, daily maximum mean temperatures were lower at the container center and occurred later in the day due to increased distance between container walls and the container center. Martin et al. (1991) concluded that, when container walls are exposed to solar radiation, increased container volume is required for maintenance of adequate carbon assimilation fluxes and tree growth.

CONTAINER COLOR AND composition. Plant growth generally increases with increasing temperature up to an optimum temperature and then decreases at higher temperatures. Favorable temperatures for root growth of northern temperate plants range from $20{ }^{\circ} \mathrm{C}$ to $30^{\circ} \mathrm{C}$ (Larcher, 1995), temperatures above $30{ }^{\circ} \mathrm{C}$ inhibit root growth (Mathers, 2003b), and temperatures above $39{ }^{\circ} \mathrm{C}$ injure roots (Johnson and Ingram, 1984). Substrate temperatures approaching those that 
cause direct injury to roots occur for about $6 \mathrm{~h}$ daily in containers exposed to full sun (Ramcharan et al., 1991). During warmer months in the southeastern United States, it is common for substrate temperatures to exceed $42{ }^{\circ} \mathrm{C}$ for several hours (Ruter and Ingram, 1990).

One method of dealing with heat stress in container production is to use containers with alternative colors or composition instead of black plastic. Black plastic pots act as heat sinks because of their ability to absorb heat from the large influx of solar radiation (Ruter, 1999). Black absorbs almost all radiation and reflects very little, and the nonporous nature of plastic allows for no evaporative cooling from container sides (Beattie et al., 1987; Ruter, 1999). It is possible that the lighter color of fiber pots allows for more reflection of radiant energy and less heat absorption than black plastic pots. Fiber pots may also have higher potential for evaporative cooling and gas exchange in comparison with black plastic pots.

The walls of fiber pots are porous and allow for evaporative cooling and gas exchange through all sides of the container, and they increase air exchange through the depth of the container (Ruter, 1999). Lower (2 to $\left.6{ }^{\circ} \mathrm{C}\right)$ maximum root zone temperatures have been reported in fiber compared with black plastic pots (Biddinger et al., 1999; Ruter, 2000). Ruter (1999) found that 'Otto Luyken' laurel (Prunus laurocersus) grew 22\% larger and had 52\% more root and shoot growth when grown in fiber pots than when grown in black plastic pots. The survival of plants in fiber containers was also higher (83\% vs. 46\%). Root growth was unaffected by pot type (plastic or fiber) until October when the rate of root growth increased and root growth of plants in fiber pots was greater than plants in plastic pots (S.B. Lowe, H.M. Mathers, and S.K. Struve, unpublished). An added benefit of fiber pots is that root development is improved by decreasing the potential for water logging.

Greene et al. (2001) compared growth of different plant species in several types of 3-gal containers. With river birch (Betula nigra) and willow oak (Quercus phellos) growing in green NS 1200 [Nursery Supplies, Fairless Hills, Pa. (NS)], green NS
1200 covered with aluminium foil, green NS Root Right (copper impregnated), and aluminium Accelerator (Hold Em, West Palm Beach, Fla.), they found temperatures in the aluminium Accelerator and aluminium foil covered containers were $\approx 10{ }^{\circ} \mathrm{F}$ cooler than the green NS 1200 and the green NS Root Right. With loblolly pine (Pinus taeda) and tulip tree (Liriodendron tulipifera) growing in green NS 1200, green NS Root Right, silver plastic Accelerator, Easi-Lift white polyethylene bag (Bong Manufacturing Co., Benicia, Calif.), copper-impregnated fiber containers (Henry Molded Products, Lebanon, Pa.), and aboveground NS 1200 inside a 5 -gal black NS container, they found that the fiber and Accelerator containers provided the coolest medium temperatures (89.2 and $91.9{ }^{\circ} \mathrm{F}$ ) but did not produce plants with the largest root and shoot dry weights. The standard black NS 1200 resulted in more vigorous growth but had the highest substrate temperatures. Pot color may have an influence on medium temperature, but ameliorating the influence of heat stress on root growth appears to be more complicated then pot color alone (i.e., pot composition, rate of substrate drying, use of chemical inhibitors, or physical root inhibitor designs also may affect root growth).

Dispersing heat energy by applying irrigation water is a method to lower substrate temperatures. Substrate composition also influences the rate of movement of heat energy (thermal diffusivity) in the container because of the differing thermal properties (i.e., thermal conductivity, $\mathrm{D}_{\mathrm{b}}$, and specific heat capacity) of individual components. For example, $26{ }^{\circ} \mathrm{C}$ irrigation water applied to $10-\mathrm{L}$ containers was most effective as a substrate coolant if sand was in the substrate compared with bark alone (Martin and Ingram, 1991). Thermal diffusivity was greatest for 3 pine bark : 2 sand substrate if volumetric water content was $10 \%$ to $65 \%$. To achieve the same cooling effect in pine bark, irrigation volumes would need to be increased or water temperatures lowered.

\section{Conclusions}

Numerous interacting abiotic factors can influence root growth of woody plants during container production. Factors most unique to container production that may have the greatest impact on root growth and establishment success of nursery stock are container characteristics and temperature. Container effects on root morphology are not well known; however, the differences in root morphology and imbalances between above- and belowground growth on nursery stock quality need further research. This type of research would help enable the development of optimal container configurations and types for specific product purposes. Much of the abiotic decline and death aboveground occurring in landscape woody plants is the result of root problems and the destruction of the absorbing organs of the plant. With an increasing amount of nursery stock being produced in containers, optimizing root growth and function and minimizing abiotic stress is important in ensuring the long-term success of the nursery/landscape industry.

\section{Literature cited}

Allaire-Leung, S.E., J. Caron, and L.E. Parent. 1999. Changes in physical properties of peat substrates during plant growth. Can. J. Soil Sci. 79:137-139.

Altland, J.E. 2006. Physical properties of container media. 29 Sept. $2006<$ http:// oregonstate.edu/dept/nursery-weeds/ feature_articles/physical_properties/ physical_properties.html>.

Altland, J.E. 2002. Herbicide timing for container weed control. Digger 46:46-48.

Appleton, B. 1993. Nursery production alternatives for reduction or elimination of circling tree roots. J. Arboriculture 19:383-388

Appleton, B. 1995. Nursery production methods for improving tree roots-an update. J. Arboriculture 21:265-270.

Argo, W.R. 1998a. Root medium chemical properties. HortTechnology 8:486494.

Argo, W.R. 1998b. Root medium physical properties. HortTechnology 8:481485 .

Argo, W.R. and P.R. Fisher. 2002. Understanding $\mathrm{pH}$ management for container-grown crops. Meister Publishing, Willoughby, Ohio.

Arnold, M.A. and G.V. McDonald. 1999. Accelerator containers alter plant growth and the rootzone environment. J. Environ. Hort. 17(4):168-173. 
Arnold, M.A. and D. Struve. 1989a. Growing green ash and red oak in $\mathrm{CuCO}_{3}$-treated containers increases root regeneration and shoot growth following transplant. J. Amer. Soc. Hort. Sci. 114:403-406.

Arnold, M.A. and D.K. Struve. 1989b. Cupric carbonate controls green ash root morphology and root growth. HortScience 24:262-264.

Arnold, M.A. and D.K. Struve. 1993. Root distribution and mineral uptake of coarse-root trees grown in cupric hydroxide-treated containers. HortScience 28:988-992.

Ashton, F.M. and A.S. Crafts. 1981. Dinitroanilines, p. 201-223. In: Mode of action of herbicides. Wiley, New York.

Beardsell, D.V., D.G. Nichols, and D.L. Jones. 1979. Physical properties of nursery potting-mixtures. Scientia Hort. $11: 1-8$.

Beattie, D.J., R. Berghage, V. Puri, and E. Biddinger. 1987. Plant growth thrives on a high fiber diet: the pros and cons of fiber containers for nursery growing. Nursery Mgt. Production 15(3):81-83

Beeson, R.C., Jr. 1996. Composted yard waste as a component of container substrates. J. Environ. Hort. 14:115-121.

Beeson, R.C., Jr. and R. Newton. 1992. Shoot and root responses of eighteen southeastern woody landscape species grown in cupric hydroxide-treated containers. J. Environ. Hort. 10:214-217.

Biddinger, E., D. Beattie, and R. Berghage. 1999. The effects of copper-treated fiber containers on the growth of four commercial plant species. Greenhouse Prod. News 9(10):23-27.

Bilderback, T.E., S.L. Warren, J.S. Owen, Jr., and J.P. Albano. 2005. Healthy substrates need physicals too. HortTechnology 15:747-751.

Bilderback, T.E. 1982. Container soils and soilless media, p. 1-12. In: V. Bonaminio (ed.). North Carolina nursery crops production manual. Bul. NCPM 9, North Carolina State University Agricultural Extension Service, Raleigh.

Bilderback, T.E. and W.C. Fonteno. 1991. Effects of container geometry and substrate physical properties on air and water volumes in containers. J. Environ. Hort. 5:180-182.

Bilderback, T.E. and R.K. Jones. 2001. Horticultural practices for reducing disease development, p. 387-400. In: R.K. Jones, and D.M. Benson (eds.). Diseases of woody ornamentals and trees in nurseries. APS Press, St. Paul, Minn.
Bishko, A.J., P.R. Fisher, and W.R. Argo. 2003. The $\mathrm{pH}$-response of a peat-based medium to application of acid reaction chemicals. HortScience 38:26-31.

Bishko, A.J., P.R. Fisher, and W.R. Argo. 2002. Quantifying the $\mathrm{pH}$-response of a peat-based medium to application of basic chemicals. HortScience 37:511-515.

Brass, T.J., G.J. Keever, C.H. Gilliam, and D.J. Eakes. 1996. Styrene-lined and copper-coated containers affect production and landscape establishment of red maple. HortScience 31:353-356.

Bunt, A.C. 1961. Some physical properties of pot plant composts and their effect on plant growth: III. Compaction. Plant Soil 15:228-242.

Cabrera, R.L. 1997. Let the nutrients flow ... slowly. Amer. Nurseryman 184:32-37.

Cameron, R.W.F., R.S. Harrison-Murray, and M.A. Scott. 1999. The use of controlled water stress to manipulate growth of container-grown rhododendron $\mathrm{cv}$. Hoppy. J. Hort. Sci. Biotechnol. 74:161-169.

Cole, D.M., J.L. Sibley, E.K. Blythe, D.J. Eakes, and K.M. Tilt. 2005. Effects of cotton gin compost on plant growth and substrate properties and growth of azalea under differing irrigation regimes in a greenhouse setting. HortTechnology 15:145-148.

Conlin, T.S.S. and R. van den Driessche. 1996. Short term effects of soil compaction on growth of Pinus contorta seedlings. Can. J. For. Res. 26:727-739.

Derr, J.F. and S. Salihu. 1996. Preemergence herbicide effects on nursery crop root and shoot growth. J. Environ. Hort. 14:210-213.

Dubik, S.P., D.T. Krizek, and D.P. Stimart. 1990. Influence of root zone restriction on mineral element concentration, water potential, chlorophyll concentration and partitioning of assimilate in spreading euonymus (E. kiautschovica Loes. 'Sieboldiana'). J. Plant Nutr. 13:677-699.

Ferree, D.C., J.G. Streeter, and Y. Yuncong. 2004. Response of container-grown apple trees to soil compaction. HortScience $39: 40-48$.

Ferrini, F., F.P. Nicese, S. Mancuso, and A. Giuntoli. 2000. Effect of nursery production method and planting techniques on tree establishment in urban sites: preliminary results. J. Arboriculture 26(5):281-283.

Fiorino, P., F.P. Nicese, M. Mingrone, and L. Riva. 1998. Effect of different type of container on nursery-grown European hornbeam (Carpinus betulus
'Pyramidalis'). Atti IV Giornate Scientifiche SOI, San Remo, Italy, 1-3 Apr., p. 199-200.

Fonteno, W.E. 1987. Choose the right container and medium. Greenhouse Grower 5:66-71.

Gilman, E.F. 2001. Effect of nursery production method, irrigation, and inoculation with mycorrhizae-forming fungi on establishment of Quercus virginiana. J. Arboriculture 27:30-39.

Gilman, E.F. and R.C. Beeson, Jr. 1996. Nursery production method affects root growth. J. Environ. Hort. 14:88-91.

Greene, V., B. Appleton, E.L. Rudiger, and G. Eaton. 2001. Reducing root zone temperatures of container-grown plants. Proc. Southern Nursery Assn. Res. Conf. 36:108-112.

Hall, C.R., A.W. Hodges, and J.J. Haydu. 2005. Economic impacts of the green industry in the United States. Updated: 06/2005. Last accessed: 01/18/2007. http://www.utextension.utk.edu/hbin/ greenimpact.html.

Handreck, K.A. 1983. Particle size and the physical properties of growing substrate for containers. Commun. Soil Sci. Plant Anal. 14:209-222.

Handreck, K.A. and N.D. Black. 1984. Growing substrate for ornamental plants and turf. New South Wales University Press, Randwick, Australia.

Hanson, A.M., J.R. Harris, and R. Wright. 2004. Effects of transplant season and container size on landscape establishment of Kalmia latifolia L. J. Environ. Hort. 22:133-138.

Harris, J.R. and E.F. Gilman. 1993. Production method affects growth and posttransplant establishment of 'East Palatka' holly. J. Amer. Soc. Hort. Sci. 118:194200.

Harris, J.R. and E.F. Gilman. 1991. Production method affects growth and root regeneration of leyland cypress laurel oak and slash pine. J. Arboriculture 17:64-69.

Harris, R.W., J.R. Clark, and N.P. Matheny. 2004. Arboriculture: integrated management of landscape trees, shrubs, and vines. Prentice Hall, Upper Saddle River, N.J.

Hayes, C.K., C.H. Gilliam, G.J. Keever, and D.J. Eakes. 1999. Effects of herbicide and time of application on pampas grass grown in containers. J. Environ. Hort. 17:185-189.

Hoitink, H.A.J., Y. Inbar, and J. Boehm. 1991. Status of compost-amended potting mixes naturally suppressive to 
soilborne diseases of floricultural crops. Plant Dis. 75:869-872.

Hoitink, H.A.J., A.G. Stone, and D.Y. Han. 1997. Suppression of plant diseases by compost. HortScience 32:184-186.

Hoitink, H.A.J. and T.J.J. DeCeuster. 1999. Using compost to control plant diseases. Biocycle 40(6):61-64.

Jarvis, B., J.B. Calkins, and B.T. Swanson. 1996. Compost and rubber tire chips as peat substitutes in nursery substrate: effects on chemical and physical substrate properties. J. Environ. Hort. 14:122-129.

Johnson, C.R. and D.L. Ingram. 1984. Pittosporum tobira response to container medium temperature. HortScience 19:524-525.

Johnson, G.R. and R. Hauer. 2000. Deep root systems affect long-term tree health and stem girdling roots. Minnesota Nursery Landscape News 24(5):18-21.

Jones, S.B. and D. Or. 1998. Design of porous substrate for optimal gas and liquid fluxes in plant roots. Soil Sci. Soc. Amer. J. 62:563-573.

Keever, G.J., G.S. Cobb, and R.B. Reed. 1985. Effect of container dimension and volume on growth of three woody ornamentals. HortScience 20:276-278.

Kraus, H.T., R.L. Mikkelsen, and S.L. Warren. 2000. Container substrate temperatures affect mineralization of composts. HortScience 35:16-18.

Kuter, G.A. 1988. Effects of municipal sludge compost curing time on suppression of Pythium and Rhizoctonia diseases of ornamental plants. Plant Dis. 72:751-756.

Larcher, W. 1995. Physiological plant ecology. 3rd ed. Springer-Verlag, Berlin.

Lauderdale, D.M., C.H. Gilliam, D.J. Eakes, G.J. Keever, and A.H. Chappelka. 1995. Tree transplant size influences posttransplant growth, gas exchange and leaf water potential of 'October Glory' red maple. J. Environ. Hort. 13:178-181.

March, H.W. and B.L. Appleton. 2004. Use of air-root-pruning containers in potin-pot systems. Proc. Southern Nursery Assn. Res. Conf. 49:51-53.

Marshall, M.D. and E.F. Gilman. 1998. Effects of nursery container type on root growth and landscape establishment of Acer rubrum L. J. Environ. Hort. 16: 55-59.

Martin, C.A. and D.L. Ingram. 1993. Container dimensions affects rooting medium temperature patterns. HortScience 28:18-19.

Martin, C.A. and D.L. Ingram. 1991. Evaluation of thermal properties and effect of irrigation on temperature dynamics in container substrate. J. Environ. Hort. 9:24-28.

Martin, C.A., D.L. Ingram, and T.A. Nell. 1991. Growth and photosynthesis of Magnolia grandiflora 'St. Mary' in response to constant and increased container volume. J. Amer. Soc. Hort. Sci. 116:439-445.

Mathers, H.M. 2004. A place to stand and a place to grow. Amer. Nurseryman 199(6):26-31.

Mathers, H.M. 2003a. Water quality for ornamentals. Amer. Nurserymen 198(5):32-34, 36-37.

Mathers, H.M. 2003b. Summary of temperature stress issues in nursery containers and current methods of protection. HortTechnology 13:617-623.

Mathers, H.M. 2002. Choosing the right herbicide. Part 1. Buckeye July:14-16.

Mathers, H.M. and P. Leidenfrost. 1995. Nursery production guide for commercial growers 1995/96 edition. British Columbia Ministry of Agriculture and Food, Victoria, BC, Canada.

Mathers, H.M., L.T. Case, E. Grosskurth, and M. Bigger. 2005. Field caliper tree production using retractable roof greenhouse grown liners. Proc. Southern Nursery Assn. Res. Conf. 50:164166.

Maupin, C. and D.K. Struve. 1997. Red oak transplanting to different bulk density soils have similar water use characteristics. J. Arboriculture 23:233-238.

Maynard, B.K., C.T. Brothers, and W.A. Johnson. 2000. Control of root circling with copper in co-extruded nursery containers. Proc. Southern Nursery Assn. Res. Conf. 45:81-84.

Meyer, M.H. and B.A. Cunliffe. 2004. Effects of substrate porosity and container size on overwintering and growth of ornamental grasses. HortScience 39: 248-250.

Milks, R.R., W.C. Fonteno, and R.A. Larson. 1989. Hydrology of horticultural substrates: II Predicting physical properties of substrate in containers. J. Amer. Soc. Hort. Sci. 114:53-56.

NeSmith, D.S. and J.D. Duval. 1998. The effects of container size. HortTechnology 8:495-498.

Newby, A. and D.C. Fare. 2001. Maple growth affected by container and liner size. Proc. Southern Nursery Assn. Res. Conf. 46:113-116.

Nillson, U. and G. Örlander. 1995. Effects of regeneration methods on drought damage to newly planted Norway spruce seedlings. Can. J. For. Res. 25:790-802.

Ownley, B.H., D.M. Benson, and T.E. Bilderback. 1990. Physical properties of container substrate and relation to severity of Phytophthora root rot of rhododendron. J. Amer. Soc. Hort. Sci. 115:564-570.

Pokorny, F.A. 1987. Available water and root development within the micropores of pine bark particles. J. Environ. Hort. 5:89-92.

Ramcharan, C., D.L. Ingram, T.A. Nell, and J.E. Barrett. 1991. Fluctuations in leaf carbon assimilation as affected by root-zone temperature and growth environment. HortScience 26:1200-1202.

Raviv, M.R. and S. Medina. 1997. Physical characteristics of separated cattle manure compost. Compost Sci. Util. 5:44-47.

Raviv, M., R. Wallach, and T.J. Blom. 2004. The effect of physical properties of soilless substrate on plant performance-a review. Acta Hort. 644:251-259.

Robbins, J.A. 2002. Effect of substrate type on the growth of container-grown woody ornamentals. Proc. Southern Nursery Assn. Res. Conf. 36:108-112.

Ruter, J.M. 2000. Biodegradable fiber containers improve the growth of two daylily cultivars. Acta Hort. 517:271-273.

Ruter, J.M. 1999. Fiber pots improve survival of 'Otto Luyken' laurel. Southern Nursery Assn. Res. Conf. 44:53-54.

Ruter, J.M. and M.P. Garber. 1993. Measuring soluble salts and $\mathrm{pH}$ with the pour-through method. University of Georgia, College Agr. Environ. Sci., Coop. Ext. Serv., Hort. Fact Sheet H-93-015.

Ruter, J.M. and D.L. Ingram. 1990. ${ }^{14}$ Carbon-labeled photosynthate partitioning in Ilex crenata 'Rotunfiolia' at supraoptimal root-zone temperatures. J. Amer. Soc. Hort. Sci. 115: 1008-1013.

Serra-Wittling, C., S. Houot, and E. Barriuso. 1996. Modification of soil water retention and biological properties by municipal solid waste compost. Compost Sci. Util. 4:44-52.

Spomer, L.A. 1974. Optimizing container soil amendment: the "threshold proportion" and prediction of porosity. HortScience 9:532-533.

Stromberger, A. 2002. Root deformities in plantations of container-grown stock; consequences for growth, stability and stem quality. Comb. Proc. Intl. Plant Prop. Soc. 52:108-113. 


\section{Reviews}

Struve, D.K., M.A. Arnold, R. Beeson, Jr., J.M. Ruter, S. Svenson, and W.T. Witte. 1994. The copper connection. Amer. Nurseryman 179:52-54, 56-61.

Swanson, B.T. 1995. ABC's of growing medium for container production. Proc. Perennial Plant Assn., Minneapolis. p. 24-35.

Thomas, P. 2000. Trees: their natural history. Cambridge University Press, Cambridge, U.K.

U.S. Department of Agriculture. 2004. Nursery crops, 2003 summary. 6 Nov. 2006 <http://usda.mannlib.cornell.edu/ reports/nassr/other/nursery/nurser04. txt>.
Weston, L.A. and B.H. Zandstra. 1986 Effect of root container size and location of production on growth and yield of tomato transplants. J. Amer. Soc. Hort. Sci. 111:498-501.

Whitcomb, C.E. 1984. Plant production in containers. Lacebark Publ., Stillwater, Okla.

Wilson, S.B., P.J. Stoffella, and D.A. Graetz. 2003. Compost-amended media and irrigation system influence containerized perennial Salvia. J. Amer. Soc. Hort. Sci. 128:260-268.

Wright, A.N., S.L. Warren, and F.A. Blazich. 2001. Exposure and plant size affect landscape establishment of Kalmia latifolia. Southern Nursery Assn. Res. Conf. 46:515-519.

Yeager, T.H., C.H. Gilliam, T.E. Bilderback, D.C. Fare, A.X. Niemiera, and K.M. Tilt. 1997. Best management practices guide for producing container-grown plants. Southern Nursery Assn., Atlanta, Ga.

Zahreddine, H.G., D.K. Struve, and M. Quigley. 2004. Growing Pinus nigra seedlings in Spinout-treated containers reduces root malformation and increases regrowth potential. J. Environ. Hort. 22:176-182. 